\title{
« Archaeological exploration in the Sogdian fortress of Kafir Kala (Samarkand region, Republic of Uzbekistan) ». Ancient Civilizations from Scythia to Siberia, 11, 2005, pp. 107-131.
}

\section{Frantz Grenet}

\section{OpenEdition}

\section{Journals}

Édition électronique

URL : http://journals.openedition.org/abstractairanica/25412

DOI : $10.4000 /$ abstractairanica. 25412

ISSN : 1961-960X

Éditeur :

CNRS (UMR 7528 Mondes iraniens et indiens), Éditions de l'IFRI

Édition imprimée

Date de publication : 15 mai 2008

ISSN : 0240-8910

\section{Référence électronique}

Frantz Grenet, « «Archaeological exploration in the Sogdian fortress of Kafir Kala (Samarkand region, Republic of Uzbekistan) ». Ancient Civilizations from Scythia to Siberia, 11, 2005, pp. 107-131. », Abstracta Iranica [En ligne], Volume 29 | 2008, document 55, mis en ligne le 15 septembre 2008, consulté le 26 septembre 2020. URL : http://journals.openedition.org/abstractairanica/25412 ; DOI : https://doi.org/10.4000/abstractairanica.25412

Ce document a été généré automatiquement le 26 septembre 2020.

Tous droits réservés 


\title{
« Archaeological exploration in the Sogdian fortress of Kafir Kala (Samarkand region, Republic of Uzbekistan) ». Ancient Civilizations from Scythia to Siberia, 11, 2005, pp. 107-131.
}

\author{
Frantz Grenet
}

Présentation des premiers résultats d'une mission conjointe de l'Université de Bologne et de l'Institut d'Archéologie de l'Académie des Sciences d'Ouzbékistan sur la rive sud de la vallée moyenne du Zarafshān et en particulier à Kafir Kala, principal site urbain de la zone, situé à l'intersection du grand canal Dargom alimentant Samarkand et de la route entre Samarkand et Kēš. Rappel des travaux soviétiques antérieurs, cartographie faisant appel aux nouvelles techniques. Plusieurs secteurs fouillés antérieurement (dont la nécropole préislamique) ont été depuis presque entièrement détruits par les travaux agricoles, mais l'énorme citadelle reste un objectif très prometteur (voir c.r. $\mathrm{n}^{\circ}$ 47). La prospection de surface indique une occupation allant du $\mathrm{IV}^{\mathrm{e}}$ au $\mathrm{VIII}^{\mathrm{e}}$ s. de n.è., avec une réoccupation partielle aux $\mathrm{XI}^{\mathrm{e}}-\mathrm{XII}^{\mathrm{e}} \mathrm{s}$.

INDEX

Thèmes : 3.1. Est de l'Iran 
AUTEURS

FRANTZ GRENET

CNRS - EPHE - Paris 